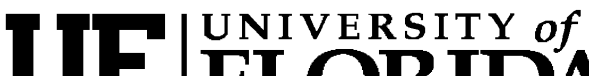 FLORIDA \\ IFAS Extension
}

\section{External Parasites of Sheep and Goats ${ }^{1}$}

\section{P. E. Kaufman, P. G. Koehler and J. F. Butler ${ }^{2}$}

Arthropod pests limit production in the sheep and goat industry in many ways. External parasites feed on body tissue such as blood, skin, and hair. The wounds and skin irritation produced by these parasites result in discomfort and irritation to the animal. Parasites can transmit diseases from sick to healthy animals. They can reduce weight gains and milk production. In general, infested livestock cannot be efficiently managed to realize optimum production levels.

\section{Lice}

Lice are external parasites which spend their entire lives on the sheep or goat. Both immature and adult stages suck the blood or feed on the skin. Goat lice are host specific and only attack goats and their close relatives such as sheep.

Louse-infested animals may be recognized by their dull, matted coat or excessive scratching and grooming behavior. Sucking lice pierce the host's skin and draw blood. Biting lice have chewing mouthparts and feed on particles of hair, scab and skin exudations. The irritation from louse-feeding causes animals to rub and scratch, causing raw areas on the skin or loss of hair. Weight loss may occur as a result of nervousness and improper nutrition. Milk production is reduced about 25 percent. Also, the host is often listless and in severe cases the loss of blood to sucking lice can lead to anemia.

Lice are generally transmitted from one animal to another by contact. Transmission from herd to herd is usually accomplished by transportation of infested animals, although some lice may move from place to place by clinging to flies (phoresy). Lice are most often introduced to herds by bringing in infested animals.

Louse populations vary seasonally, depending largely on the condition of the host. Most sucking and biting lice begin to increase in number during the fall and reach peak populations in late winter or early spring. Summer populations are usually minimal, causing no obvious symptoms. Animals under stress will usually support larger louse populations than normally found.

1. This document is ENY-273 (IG129), one of a series of the Entomology and Nematology Department, Florida Cooperative Extension Service, Institute of Food and Agricultural Sciences, University of Florida. Publication date: July 1993. Revised: March 2006. Please visit the EDIS Website at http://edis.ifas.ufl.edu.

2. P. E. Kaufman, assistant professor, P. G. Koehler, professor/extension entomologist and J. F. Butler, professor, Entomology and Nematology Department, Cooperative Extension Service, Institute of Food and Agricultural Sciences, University of Florida, Gainesville, 32611.

The use of trade names in this publication is solely for the purpose of providing specific information. UF/IFAS does not guarantee or warranty the products named, and references to them in this publication does not signify our approval to the exclusion of other products of suitable composition. All chemicals should be used in accordance with directions on the manufacturer's label. Use pesticides safely. Read and follow directions on the manufacturer's label. 
Control of louse infestations is needed whenever an animal scratches and rubs to excess. Louse control is difficult since pesticides do not kill the louse egg. Since eggs of most species will hatch 8 to 12 days after pesticide application, retreatment is necessary 2 weeks after the first pesticide application.

There are 4 kinds of biting lice and 5 kinds of sucking lice that can attack sheep and goats in Florida.

\section{Biting Lice}

The angora goat biting louse, Bovicola limbata and Holokartikos crassipes are the two major biting lice species. The goat biting louse (Figure 1) and the sheep biting louse are of lesser significance.

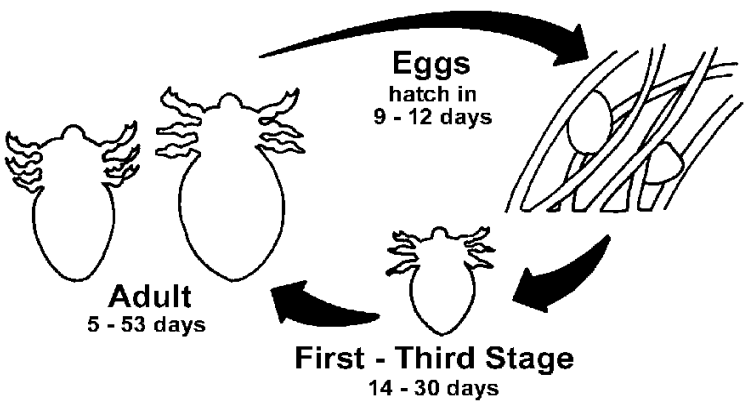

Figure 1. Goat biting louse life cycle. Credits: J. F. Butler, University of Florida

All four species live on the skin surface feeding on scales, bits of hair and other skin surface debris. Egg hatch requires 9 to 12 days, and the entire life cycle averages 1 month. The biting lice of goats are world-wide in distribution with winter-time populations being most severe. In Florida high populations have been observed year round.

The best control of biting lice is an animal residual spray. Retreatment is recommended 2 weeks after the first pesticide application for most insecticides.

\section{Sucking Lice}

Five species of sucking lice attack sheep and goats. The following are of importance:

1. African blue louse - Found in semi-tropical climates in the United States, India and Puerto Rico. They are found on the body, head, and neck. Heavy populations have caused the death of the host.

2. Foot louse - This louse prefers the feet and legs of goats and sheep. Populations peak in the spring and at that time the lice may affect the belly area as well. Scrotum infestations on bucks are common. Lambs seem to have the highest infestations. Egg hatch for this species of louse takes longer than the other species. Therefore, retreatment should be applied after 3 weeks for most insecticides.

3. Goat sucking louse - Populations (Figure 2) are dispersed over the animal's body. It is also found on sheep.

\section{The face and body louse and the long-nosed cattle louse - These are minor pests.}

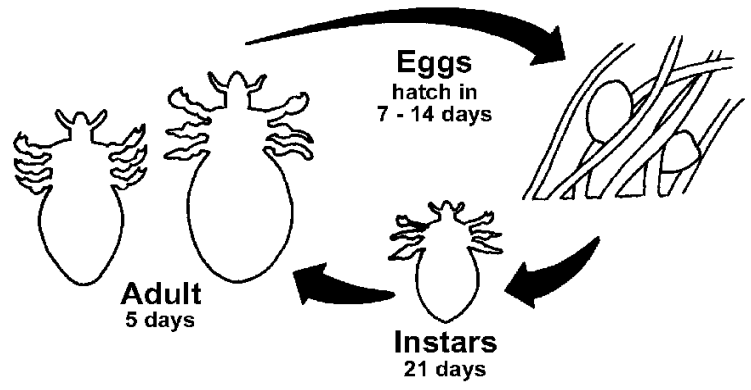

Figure 2. Goat sucking louse life cycle.

\section{Nose Bot Fly}

The nose bot fly (Figure 3 ) infests the nostrils of sheep and goats. In infested animals, there is a discharge from the nostrils, biforous shaking of the head, loss of appetite and grating of the teeth. In the presence of the adult fly, the animals are excited, shake their heads, snort and rush with their noses in the dust.

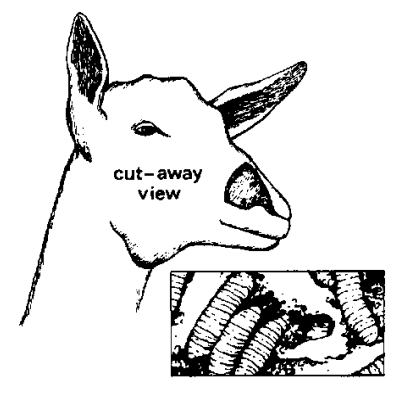

Figure 3. Nose bot flies. 
Nose bot flies are a winter-time problem. Up to 25 bots have been found in the nasal passages of sheep in Florida. They may cause eye damage in man. The larvae of the fly are laid in the nostrils. They migrate up the nasal passages and feed on mucous and mucous membranes. Currently, an ivermectin oral dreanch is the only available treatment.

\section{Keds}

Keds (Figure 4) (Hippoboscidae), also known as louse flies, are large, flattened, usually wingless parasitic flies. Two species feed on goats, but one reproduces on deer and feeds on sheep. Sheep ked bites cause irritation and prompt the infested animals to rub, bite, and scratch. They may also roll on the ground in an attempt to relieve irritation.

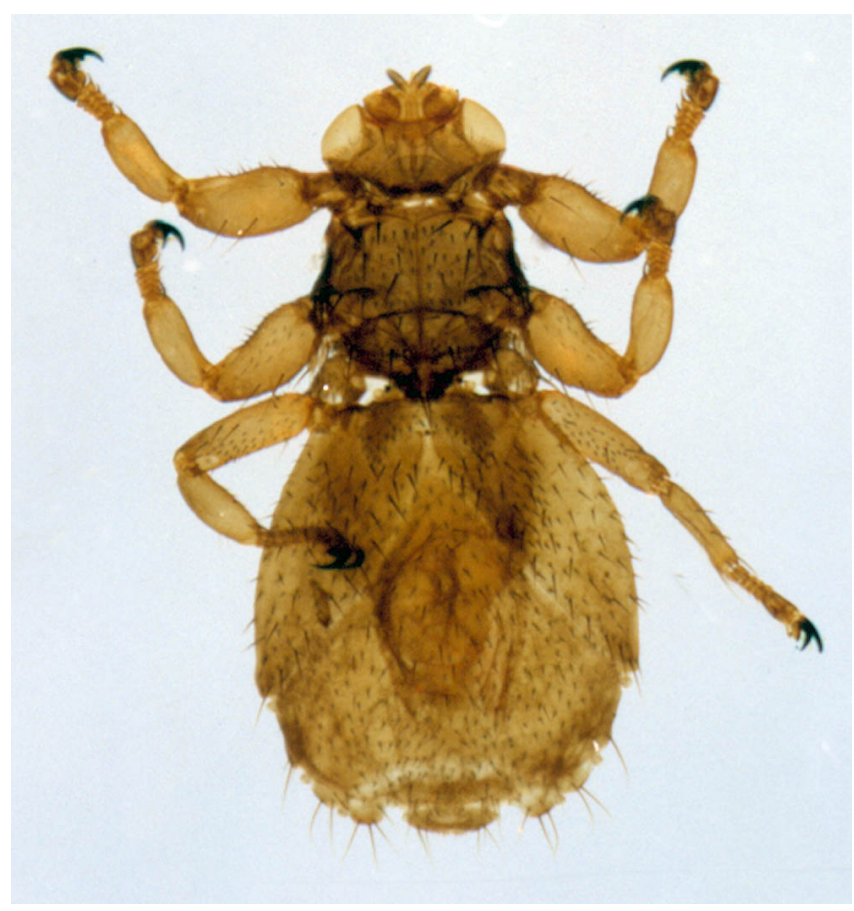

Figure 4. Ked. Credits: J. F. Butler, University of Florida

Keds usually do not cause great damage if the animal is fed on a highly nutritious diet, but sheep grazed throughout the year on pasture or range may acquire heavy burdens of keds during winter and early spring.

Eggs are retained and hatch within the body of the female ked and develop into fully grown larvae ready to pupate. These larvae are then glued to hairs of the host. A female ked is capable of developing only one larva at a time. During the female's life of 100 to 130 days, she produces around 10 to 15 young, giving birth every 8 to 9 days. The pupal stage lasts from 18 to 30 days.

\section{Infestations of Fly Maggots}

Fly maggots, (Myiasis), is the presence of fly larvae in the living host. Several kinds of maggots infest the wounds of warm-blooded animals; however, the only one that feeds exclusively on live flesh is the primary screwworm. Sterile male releases have irradiated the primary screwworm fly from the Southeast; but there is constant danger of reinfestation.

Other species such as the secondary screwworm and other blow flies may also infest wounds. These species normally lay their eggs on carcasses of dead animals and may occasionally occur in open wounds. Although these species may cause worry, they will not consume living flesh and will feed only on dead flesh and wound secretions. Infestations of secondary screwworm often follows an injury which produces untreated wounds or management practices which allow animals to develop bacterial skin infestations. These problems must be cleared up to prevent secondary screwworm infestation.

There is no simple way to differentiate between primary screwworm and other fly larvae. Any suspected screwworm case should be reported to the county extension director. Samples of eggs and maggots should be saved in a small container filled with a $70 \%$ alcohol solution.

\section{Mites}

Itch or mange mites (Figure 5) (Psoroptes, Sarcoptes) feed on the surface or burrow within the skin, making very slender, winding tunnels from 0.1 to 1 inch long. The fluid discharged at the tunnel openings dries to form nodules. A toxin is also secreted which causes intense irritation and itching. Infested animals rub and scratch continuously. Infestations are contagious and treatment of all animals in a herd is essential to achieve control. Delayed egg hatch requires retreatment at 10 days. 


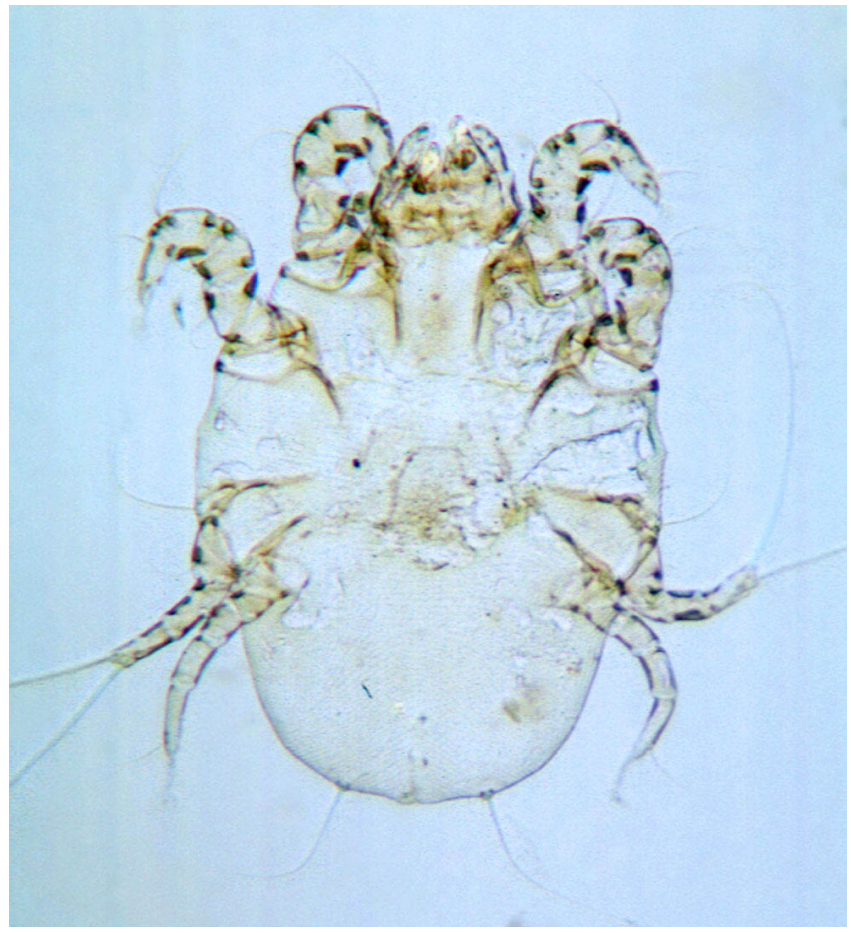

Figure 5. Itch mite. Credits: J. F. Butler, University of Florida

The most common mange of sheep and goats is Psoroptic ear mite (Psoroptes caniculi) or scab mite. It lives in the auditory canal and temporarily on the body.

\section{Fleas (Siphonaptera)}

Fleas are small, wingless insects varying from 1.0 to $8.5 \mathrm{~mm}$ in length. They are narrow insects compressed on the sides with spines directed backwards.

Most species move about a great deal and remain on the host only part of the time to obtain a blood meal. The legs are well developed and they can jump as far as 7 to 8 inches.

The flea has 4 life stages: egg, larva, pupa, and adult. Under favorable conditions, a generation can be completed in as little as 2 to 3 weeks. Mating takes place on the host and eggs are laid on the host. Since they are not attached, the eggs drop to the ground and hatch in from 2 days to several weeks. Development occurs most commonly in the bedding of the resting area of the host.

The larvae (Figure 6) are very small worm-like, legless insects with chewing mouthparts. In several weeks they go through 3 larval stages, feeding on organic debris. The pupal stage lasts approximately one week, then the newly emerged adult flea is ready to feed on blood within 24 hours.

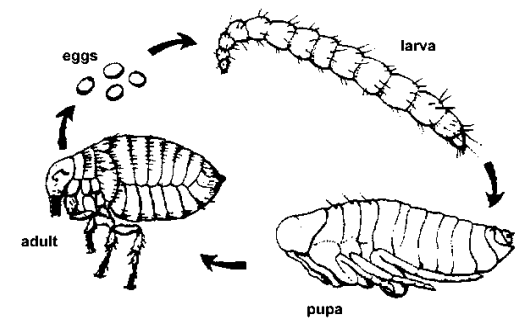

Figure 6. Flea life cycle. Credits: J. F. Butler, University of Florida

The sticktight flea (Figure 7), is the most common flea on sheep and goats. It attaches firmly to its host usually about the face and ears. This species remains attached to its host for as long as 2 to 3 weeks. During this time eggs are laid. They drop to the ground and hatch into larvae. Large populations of this flea may cause ulcers on the head and ears. Flea infestations often spread to other animals including man.

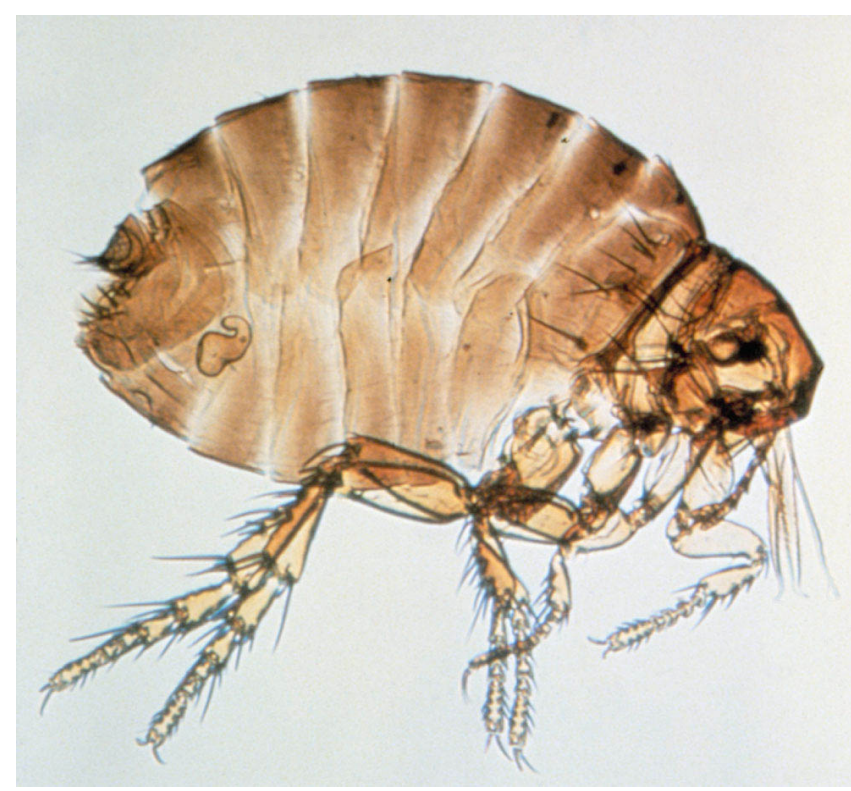

Figure 7. Sticktight flea. Credits: J. F. Butler, University of Florida 


\section{External Parasite Control Recommendations for Dairy Goats}

Very few pesticides are registered for control of parasites on dairy goats. Read all warnings, directions, and precautions carefully to insure proper usage.

\section{Keys to Pesticide Safety}

1. Before using any pesticide, stop and read the precautions.

2. Read the label on each pesticide container before each use. Heed all warnings and precautions.

3. Store all pesticides in their original container away from food or feed.

4. Keep pesticides out of the reach of children, pets, and livestock.

5. Apply pesticides only as directed.

6. Dispose of empty containers promptly and safely.

These recommendations are guidelines only. The user must insure that the pesticide is applied in strict compliance with label directions.

The Food and Drug Administration has established residue tolerances for certain insecticides in the meat and milk of certain animals. When these and other approved insecticides are applied according to recommendations, the pests should be effectively controlled and the animals' products will be safe for use as food.

The improper use of insecticides may result in residue in milk or meat. Such products must not be delivered to processing plants.

To avoid excessive residues, use the insecticides recommended at the time recommended and in the amounts recommended. Remember that goats are smaller animals than cattle and require proportionately less pesticide for adequate treatment. Be careful not to over treat animals. Spray with enough pressure to penetrate the hair coat and wet the skin. Less than 1 quart of spray should be enough to produce complete coverage per animal.

\section{Selected References}

Butler, J. F. 1985. Lice affecting livestock. In: Livestock Entomology (R. E. Williams, R. D. Hall, A. B. Broce and P. J. Scholl, eds.), pp. 101-127. Wiley, New York.

Catts, E. P and G. R. Mullen. 2002. Myiasis (Muscoidea, Oestroidea), In: Medical and Veterinary Entomology, (G. R. Mullen and L. A. Durden, Eds.), pp.318-348. Elsevier Science, San Diego, CA.

Durden, L. A. 2002. Lice (Phthiraptera), In: Medical and Veterinary Entomology, (G. R. Mullen and L. A. Durden, Eds.), pp.45-65. Elsevier Science, San Diego, CA.

Lloyd, J. E. 1985. Arthropod pests of beef cattle on pastures and range land In: Livestock Entomology (R. E. Williams, R. D. Hall, A. B. Broce and P. J. Scholl, eds.), pp. 253-268. Wiley, New York.

Lloyd, J. E. 2002. Louse flies, keds and related flies (Hippoboscoidea), In: Medical and Veterinary Entomology, (G. R. Mullen and L. A. Durden, Eds.), pp.349-362. Elsevier Science, San Diego, CA.

Lloyd, J. E., R. E. Pfadt and E. J. Olson. 1982. Sheep ked control with pour-on applications of organophosphorus insecticides. J. Econ. Entomol. 75: 5-6.

Moon, R. D. 2002. Muscoid flies (Muscidae), In: Medical and Veterinary Entomology, (G. R. Mullen and L. A. Durden, Eds.), pp.45-65. Elsevier Science, San Diego, CA.

Mullen, G. R. and B. M. OConnor. 2002. Mites (Acari), In: Medical and Veterinary Entomology, (G. R. Mullen and L. A. Durden, Eds.), pp.449-517. Elsevier Science, San Diego, CA.

Nelson, W. A. 1958. Transfer of sheep keds, Melophagus ovinus (L.) from ewes to their lambs. Nature. 181: 56. 
Table 1. Summary of Sheep Insecticide Registrations.

\begin{tabular}{|c|c|c|c|c|}
\hline Insecticide & Formulation & $\begin{array}{l}\% \text { Active } \\
\text { Ingredient }\end{array}$ & Signal Word & Pests \\
\hline \multicolumn{5}{|l|}{ Permethrin } \\
\hline $\begin{array}{l}\text { Atroban } 11 \% \text { EC } \\
\text { Insecticide }\end{array}$ & $\begin{array}{l}\text { Emulsifiable } \\
\text { Concentrate }\end{array}$ & $11.0 \%$ & & $\begin{array}{l}\text { black flies, eye gnats, horn flies, } \\
\text { horse flies, house flies, lice, mange } \\
\text { mites, mosquitoes, scabies mites, } \\
\text { sheep keds, stable flies, ticks (Reg } \\
\text { 06/07) }\end{array}$ \\
\hline Atroban $42.5 \%$ EC & $\begin{array}{l}\text { Emulsifiable } \\
\text { Concentrate }\end{array}$ & $42.5 \%$ & Danger & $\begin{array}{l}\text { horn flies, horse flies, house flies, } \\
\text { lice, mites, mosquitoes, stable flies, } \\
\text { ticks (Reg 06/07) }\end{array}$ \\
\hline $\begin{array}{l}\text { Atroban Delice Pour-On } \\
\text { Insecticide }\end{array}$ & Pour-On & $1.0 \%$ & & keds, lice (Reg 06/07) \\
\hline Catron IV & Aerosol & $0.5 \%$ & Caution & $\begin{array}{l}\text { deer flies, horn flies, horse flies, } \\
\text { house flies, gnats, stable flies, ear } \\
\text { ticks, screwworms, fleece worms } \\
\text { (Reg 06/07) }\end{array}$ \\
\hline GardStar $40 \%$ EC & $\begin{array}{l}\text { Emulsifiable } \\
\text { Concentrate }\end{array}$ & $40.0 \%$ & Danger & $\begin{array}{l}\text { black flies, deer flies, eye gnats, } \\
\text { horn flies, horse flies, house flies, } \\
\text { lice, mange mites, mosquitoes, } \\
\text { scabies mites, sheep keds, stable } \\
\text { flies, ticks (Reg 03/06) }\end{array}$ \\
\hline Ultra Boss Pour-On & Pour-On & $5.0 \%$ & Caution & keds, lice (Reg 06/07) \\
\hline \multicolumn{5}{|l|}{ Permethrin (synergized) } \\
\hline $\begin{array}{l}\text { Synergized Delice } \\
\text { Pour-On Insecticide }\end{array}$ & Pour-On & $1.0 \%$ & & keds, lice (Reg 06/07) \\
\hline \multicolumn{5}{|l|}{ Zeta-cypermethrin } \\
\hline Python Dust & Dust & $0.075 \%$ & Caution & $\begin{array}{l}\text { horn flies, keds, lice, ticks } \\
\text { (Reg 03/06) }\end{array}$ \\
\hline
\end{tabular}


Table 2. Registered Insecticides for Specific Sheep Pests.

\begin{tabular}{|c|c|c|c|}
\hline Insecticide & Formulation & $\begin{array}{l}\text { Re-Treatment } \\
\text { Interval }\end{array}$ & Comments from Label \\
\hline \multicolumn{4}{|c|}{ Black Flies } \\
\hline $\begin{array}{l}\text { Atroban } 11 \% \text { EC Insecticide } \\
\text { (permethrin) }\end{array}$ & $\begin{array}{l}\text { Emulsifiable } \\
\text { Concentrate }\end{array}$ & 2 weeks & $\begin{array}{l}\text { Mix thoroughly according to label directions. } \\
\text { (Reg 06/07) }\end{array}$ \\
\hline \multicolumn{4}{|c|}{ Blow Flies } \\
\hline $\begin{array}{l}\text { Permectrin II } \\
\text { (permethrin) }\end{array}$ & $\begin{array}{l}\text { Emulsifiable } \\
\text { Concentrate }\end{array}$ & 2 weeks & Spray or dip animals. (Reg 06/07) \\
\hline Catron IV (permethrin) & Aerosol & & $\begin{array}{l}\text { Spray according to label directions. } \\
\text { (Reg 06/07) }\end{array}$ \\
\hline $\begin{array}{l}\text { GardStar } 40 \% \text { EC } \\
\text { (permethrin) }\end{array}$ & $\begin{array}{l}\text { Emulsifiable } \\
\text { Concentrate }\end{array}$ & 10-14 days & $\begin{array}{l}\text { Dilute and apply according to label directions. } \\
\text { May be used as a high pressure spray, low } \\
\text { pressure spray (hand-pump sprayer), or } \\
\text { backrubber. (Reg 03/06) }\end{array}$ \\
\hline \multicolumn{4}{|c|}{ Eye Gnats } \\
\hline $\begin{array}{l}\text { Atroban } 11 \% \text { EC Insecticide } \\
\text { (permethrin) }\end{array}$ & $\begin{array}{l}\text { Emulsifiable } \\
\text { Concentrate }\end{array}$ & 2 weeks & $\begin{array}{l}\text { Mix thoroughly according to label directions. } \\
\text { (Reg 06/07) }\end{array}$ \\
\hline \multicolumn{4}{|c|}{ Fleece Worms } \\
\hline Catron IV (permethrin) & Aerosol & & $\begin{array}{l}\text { Spray according to label directions. } \\
\text { (Reg 06/07) }\end{array}$ \\
\hline \multicolumn{4}{|c|}{ Horn Flies } \\
\hline $\begin{array}{l}\text { Atroban } 11 \% \text { EC Insecticide } \\
\text { (permethrin) }\end{array}$ & $\begin{array}{l}\text { Emulsifiable } \\
\text { Concentrate }\end{array}$ & 2 weeks & $\begin{array}{l}\text { Mix thoroughly according to label directions. } \\
\text { (Reg 06/07) }\end{array}$ \\
\hline $\begin{array}{l}\text { Atroban } 42.5 \% \text { EC } \\
\text { (permethrin) }\end{array}$ & $\begin{array}{l}\text { Emulsifiable } \\
\text { Concentrate }\end{array}$ & 10 to 14 days & $\begin{array}{l}\text { Apply diluted product, according to label } \\
\text { directions as a dip or spray. (Reg 06/07) }\end{array}$ \\
\hline Catron IV (permethrin) & Aerosol & & $\begin{array}{l}\text { Spray according to label directions. } \\
\text { (Reg 06/07) }\end{array}$ \\
\hline $\begin{array}{l}\text { GardStar } 40 \% \text { EC } \\
\text { (permethrin) }\end{array}$ & $\begin{array}{l}\text { Emulsifiable } \\
\text { Concentrate }\end{array}$ & 10-14 days & $\begin{array}{l}\text { Dilute and apply according to label directions. } \\
\text { May be used as a high pressure spray, low } \\
\text { pressure spray (hand-pump sprayer), or } \\
\text { backrubber. (Reg 03/06) }\end{array}$ \\
\hline
\end{tabular}


Table 2. Registered Insecticides for Specific Sheep Pests.

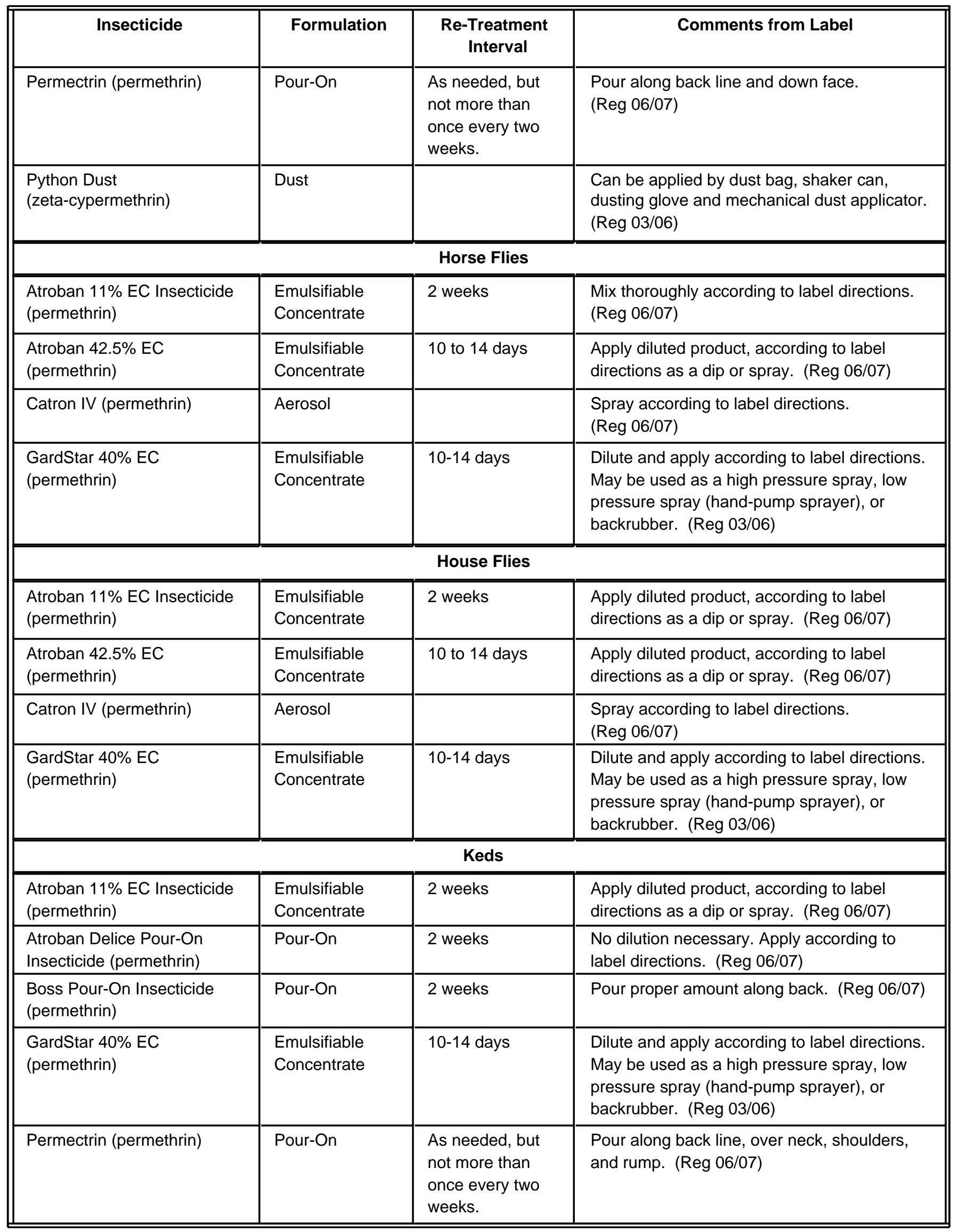


Table 2. Registered Insecticides for Specific Sheep Pests.

\begin{tabular}{|c|c|c|c|}
\hline Insecticide & Formulation & $\begin{array}{l}\text { Re-Treatment } \\
\text { Interval }\end{array}$ & Comments from Label \\
\hline $\begin{array}{l}\text { Permectrin CDS } \\
\text { (permethrin) }\end{array}$ & Pour-On & & $\begin{array}{l}\text { Pour along back. For optimum control, all } \\
\text { animals in flock should be treated after } \\
\text { shearing. (Reg 06/07) }\end{array}$ \\
\hline $\begin{array}{l}\text { Python Dust } \\
\text { (zeta-cypermethrin) }\end{array}$ & Dust & & $\begin{array}{l}\text { Can be applied by dust bag, shaker can, } \\
\text { dusting glove and mechanical dust applicator. } \\
\text { (Reg 03/06) }\end{array}$ \\
\hline $\begin{array}{l}\text { Synergized Delice Pour-On } \\
\text { Insecticide } \\
\text { (permethrin -synergized) }\end{array}$ & Pour-On & 14 days & $\begin{array}{l}\text { Pour along back. For optimum control, all } \\
\text { animals in flock should be treated after } \\
\text { shearing. (Reg 06/07) }\end{array}$ \\
\hline $\begin{array}{l}\text { Ultra Boss Pour-On } \\
\text { (permethrin) }\end{array}$ & Pour-On & 2 weeks & Pour along back. (Reg 06/07) \\
\hline $\begin{array}{l}\text { Atroban } 11 \% \text { EC Insecticide } \\
\text { (permethrin) }\end{array}$ & $\begin{array}{l}\text { Emulsifiable } \\
\text { Concentrate }\end{array}$ & 2 weeks & $\begin{array}{l}\text { Apply diluted product, according to label } \\
\text { directions as a dip or spray. (Reg 06/07) }\end{array}$ \\
\hline $\begin{array}{l}\text { Atroban Delice Pour-On } \\
\text { Insecticide (permethrin) }\end{array}$ & Pour-On & 2 weeks & $\begin{array}{l}\text { No dilution necessary. Apply according to } \\
\text { label directions. (Reg 06/07) }\end{array}$ \\
\hline $\begin{array}{l}\text { Boss Pour-On Insecticide } \\
\text { (permethrin) }\end{array}$ & Pour-On & 2 weeks & $\begin{array}{l}\text { Pour proper amount along back. For optimum } \\
\text { lice control, two treatments at } 14 \text { day intervals } \\
\text { are recommended. (Reg 06/07) }\end{array}$ \\
\hline $\begin{array}{l}\text { GardStar } 40 \% \text { EC } \\
\text { (permethrin) }\end{array}$ & $\begin{array}{l}\text { Emulsifiable } \\
\text { Concentrate }\end{array}$ & $10-14$ days & $\begin{array}{l}\text { Dilute and apply according to label directions. } \\
\text { May be used as a high pressure spray, low } \\
\text { pressure spray (hand-pump sprayer), or } \\
\text { backrubber. (Reg 03/06) }\end{array}$ \\
\hline Permectrin CDS (permethrin) & Pour-On & & $\begin{array}{l}\text { Pour along back. For optimum control, all } \\
\text { animals in flock should be treated after } \\
\text { shearing. (Reg 06/07) }\end{array}$ \\
\hline $\begin{array}{l}\text { Permectrin II } \\
\text { (permethrin) }\end{array}$ & $\begin{array}{l}\text { Emulsifiable } \\
\text { Concentrate }\end{array}$ & 2 weeks & Spray or dip animals. (Reg 06/07) \\
\hline $\begin{array}{l}\text { Python Dust } \\
\text { (zeta-cypermethrin) }\end{array}$ & Dust & & $\begin{array}{l}\text { Can be applied by dust bag, shaker can, } \\
\text { dusting glove and mechanical dust applicator. } \\
\text { (Reg 03/06) }\end{array}$ \\
\hline $\begin{array}{l}\text { Synergized Delice Pour-On } \\
\text { Insecticide } \\
\text { (permethrin - synergized) }\end{array}$ & Pour-On & 14 days & $\begin{array}{l}\text { Pour along back. For optimum control, all } \\
\text { animals in flock should be treated after } \\
\text { shearing. (Reg 06/07) }\end{array}$ \\
\hline $\begin{array}{l}\text { Ultra Boss Pour-On } \\
\text { (permethrin) }\end{array}$ & Pour-On & 2 weeks & $\begin{array}{l}\text { Pour along back. For optimum lice control, two } \\
\text { treatments at } 14 \text {-day intervals are } \\
\text { recommended. (Reg 06/07) }\end{array}$ \\
\hline \multicolumn{4}{|c|}{ Mites (Mange) } \\
\hline $\begin{array}{l}\text { Atroban } 11 \% \text { EC Insecticide } \\
\text { (permethrin) }\end{array}$ & $\begin{array}{l}\text { Emulsifiable } \\
\text { Concentrate }\end{array}$ & 2 weeks & $\begin{array}{l}\text { Apply diluted product, according to label } \\
\text { directions as a dip or spray. (Reg 06/07) }\end{array}$ \\
\hline
\end{tabular}


Table 2. Registered Insecticides for Specific Sheep Pests.

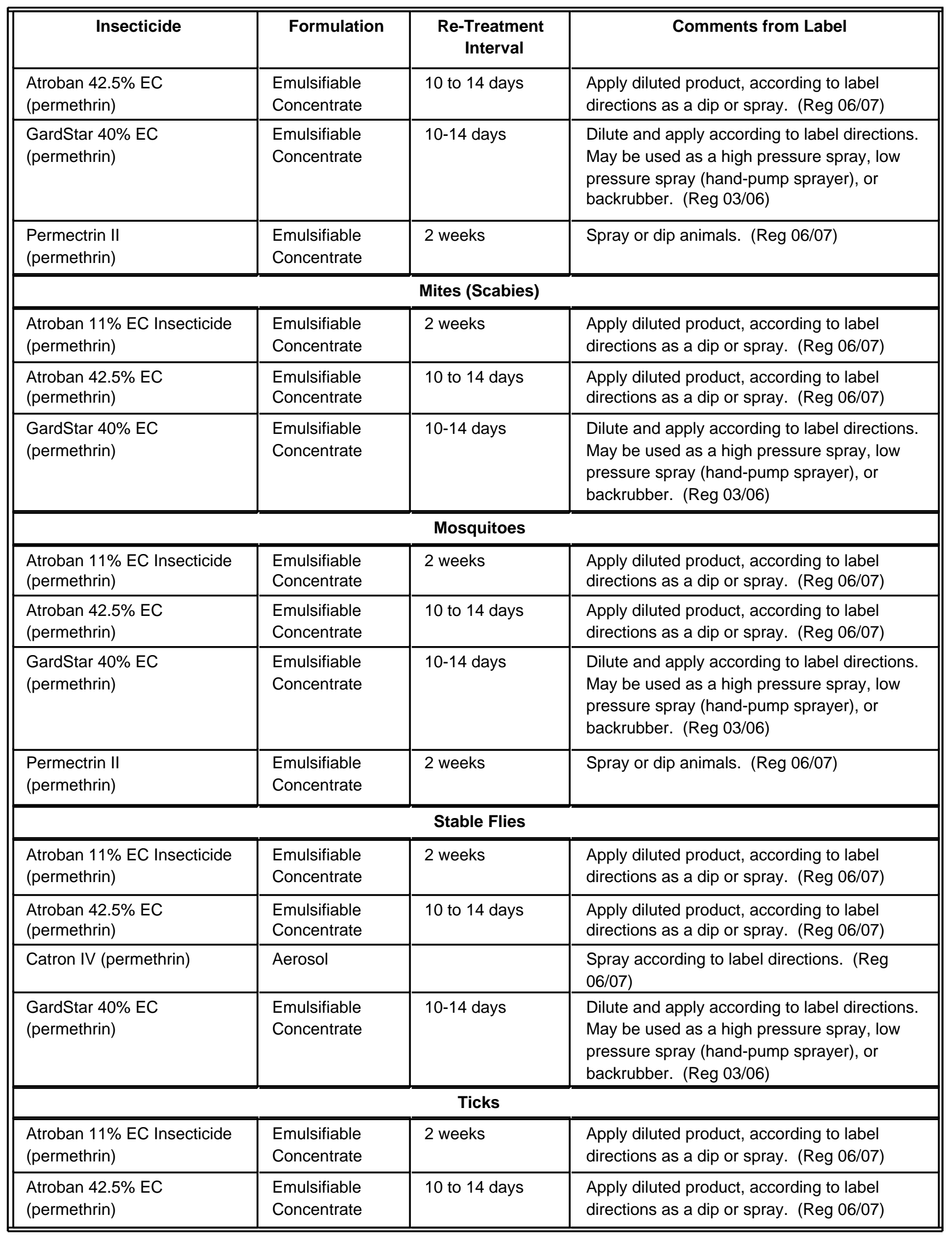


Table 2. Registered Insecticides for Specific Sheep Pests.

\begin{tabular}{|c|c|c|c|}
\hline Insecticide & Formulation & $\begin{array}{l}\text { Re-Treatment } \\
\text { Interval }\end{array}$ & Comments from Label \\
\hline Catron IV (permethrin) & Aerosol & & $\begin{array}{l}\text { Spray according to label directions. (Reg } \\
06 / 07)\end{array}$ \\
\hline $\begin{array}{l}\text { GardStar } 40 \% \text { EC } \\
\text { (permethrin) }\end{array}$ & $\begin{array}{l}\text { Emulsifiable } \\
\text { Concentrate }\end{array}$ & 10-14 days & $\begin{array}{l}\text { Dilute and apply according to label directions. } \\
\text { May be used as a high pressure spray, low } \\
\text { pressure spray (hand-pump sprayer), or } \\
\text { backrubber. (Reg 03/06) }\end{array}$ \\
\hline $\begin{array}{l}\text { Permectrin II } \\
\text { (permethrin) }\end{array}$ & $\begin{array}{l}\text { Emulsifiable } \\
\text { Concentrate }\end{array}$ & 2 weeks & Spray or dip animals. (Reg 06/07) \\
\hline $\begin{array}{l}\text { Python Dust } \\
\text { (zeta-cypermethrin) }\end{array}$ & Dust & & $\begin{array}{l}\text { Can be applied by dust bag, shaker can, } \\
\text { dusting glove and mechanical dust applicator. } \\
\text { (Reg 03/06) }\end{array}$ \\
\hline Catron IV (permethrin) & Aerosol & & $\begin{array}{l}\text { Spray according to label directions. } \\
\text { (Reg 06/07) }\end{array}$ \\
\hline
\end{tabular}

Table 3. Summary of Goat Insecticide Registrations.

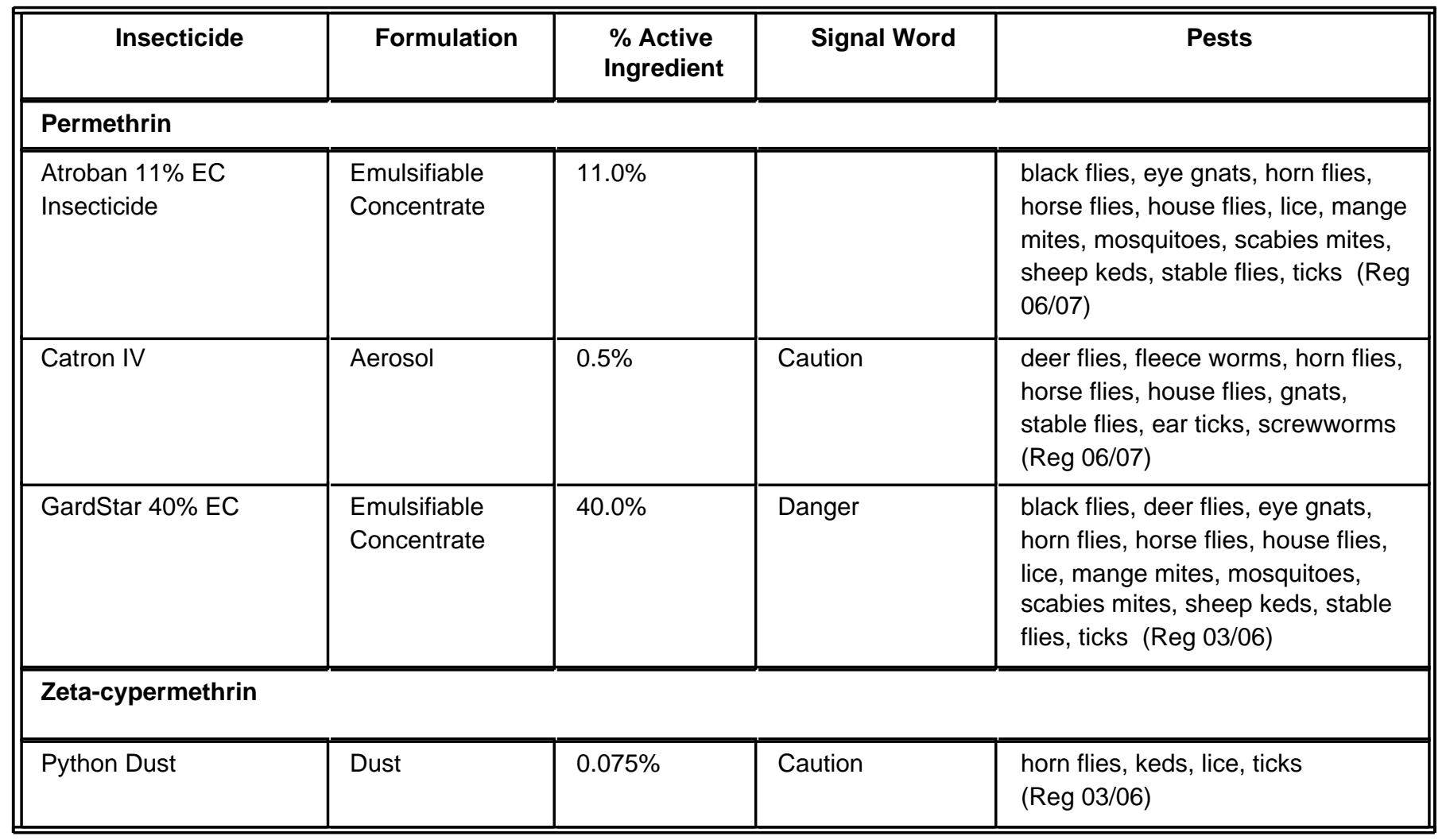


Table 4. Registered Insecticides for Specific Goat (lactating and non-lactating) Pests.

\begin{tabular}{|c|c|c|c|}
\hline Insecticide & Formulation & $\begin{array}{l}\text { Re-Treatment } \\
\text { Interval }\end{array}$ & Comments from Label \\
\hline \multicolumn{4}{|c|}{ Black Flies } \\
\hline $\begin{array}{l}\text { Atroban } 11 \% \text { EC Insecticide } \\
\text { (permethrin) }\end{array}$ & $\begin{array}{l}\text { Emulsifiable } \\
\text { Concentrate }\end{array}$ & 2 weeks & $\begin{array}{l}\text { Mix thoroughly according to label directions. } \\
\text { (Reg 06/07) }\end{array}$ \\
\hline \multicolumn{4}{|c|}{ Deer Flies } \\
\hline Catron IV (permethrin) & Aerosol & & $\begin{array}{l}\text { Spray according to label directions. } \\
\text { (Reg 06/07) }\end{array}$ \\
\hline \multicolumn{4}{|c|}{ Eye Gnats } \\
\hline $\begin{array}{l}\text { Atroban } 11 \% \text { EC Insecticide } \\
\text { (permethrin) }\end{array}$ & $\begin{array}{l}\text { Emulsifiable } \\
\text { Concentrate }\end{array}$ & 2 weeks & $\begin{array}{l}\text { Mix thoroughly according to label directions. } \\
\text { (Reg 06/07) }\end{array}$ \\
\hline Catron IV (permethrin) & Aerosol & & $\begin{array}{l}\text { Spray according to label directions. } \\
\text { (Reg 06/07) }\end{array}$ \\
\hline $\begin{array}{l}\text { GardStar } 40 \% \text { EC } \\
\text { (permethrin) }\end{array}$ & $\begin{array}{l}\text { Emulsifiable } \\
\text { Concentrate }\end{array}$ & $10-14$ days & $\begin{array}{l}\text { Dilute and apply according to label directions. } \\
\text { May be used as a high pressure spray, low } \\
\text { pressure spray (hand-pump sprayer), or } \\
\text { backrubber. (Reg 03/06) }\end{array}$ \\
\hline \multicolumn{4}{|c|}{ Horn Flies } \\
\hline $\begin{array}{l}\text { Atroban } 11 \% \text { EC Insecticide } \\
\text { (permethrin) }\end{array}$ & $\begin{array}{l}\text { Emulsifiable } \\
\text { Concentrate }\end{array}$ & 2 weeks & $\begin{array}{l}\text { Mix thoroughly according to label directions. } \\
\text { (Reg 06/07) }\end{array}$ \\
\hline Catron IV (permethrin) & Aerosol & & $\begin{array}{l}\text { Spray according to label directions. } \\
\text { (Reg 06/07) }\end{array}$ \\
\hline $\begin{array}{l}\text { GardStar } 40 \% \text { EC } \\
\text { (permethrin) }\end{array}$ & $\begin{array}{l}\text { Emulsifiable } \\
\text { Concentrate }\end{array}$ & 10-14 days & $\begin{array}{l}\text { Dilute and apply according to label directions. } \\
\text { May be used as a high pressure spray, low } \\
\text { pressure spray (hand-pump sprayer), or } \\
\text { backrubber. (Reg 03/06) }\end{array}$ \\
\hline $\begin{array}{l}\text { Python Dust } \\
\text { (zeta-cypermethrin) }\end{array}$ & Dust & & $\begin{array}{l}\text { Can be applied by dust bag, shaker can, } \\
\text { dusting glove and mechanical dust applicator. } \\
\text { (Reg 03/06) }\end{array}$ \\
\hline \multicolumn{4}{|c|}{ Horse Flies } \\
\hline $\begin{array}{l}\text { Atroban } 11 \% \text { EC Insecticide } \\
\text { (permethrin) }\end{array}$ & $\begin{array}{l}\text { Emulsifiable } \\
\text { Concentrate }\end{array}$ & 2 weeks & $\begin{array}{l}\text { Mix thoroughly according to label directions. } \\
\text { (Reg 06/07) }\end{array}$ \\
\hline
\end{tabular}


Table 4. Registered Insecticides for Specific Goat (lactating and non-lactating) Pests.

\begin{tabular}{|c|c|c|c|}
\hline Insecticide & Formulation & $\begin{array}{l}\text { Re-Treatment } \\
\text { Interval }\end{array}$ & Comments from Label \\
\hline Catron IV (permethrin) & Aerosol & & $\begin{array}{l}\text { Spray according to label directions. } \\
\text { (Reg 06/07) }\end{array}$ \\
\hline $\begin{array}{l}\text { GardStar } 40 \% \text { EC } \\
\text { (permethrin) }\end{array}$ & $\begin{array}{l}\text { Emulsifiable } \\
\text { Concentrate }\end{array}$ & $10-14$ days & $\begin{array}{l}\text { Dilute and apply according to label directions. } \\
\text { May be used as a high pressure spray, low } \\
\text { pressure spray (hand-pump sprayer), or } \\
\text { backrubber. (Reg 03/06) }\end{array}$ \\
\hline \multicolumn{4}{|c|}{ House Flies } \\
\hline $\begin{array}{l}\text { Atroban } 11 \% \text { EC Insecticide } \\
\text { (permethrin) }\end{array}$ & $\begin{array}{l}\text { Emulsifiable } \\
\text { Concentrate }\end{array}$ & 2 weeks & $\begin{array}{l}\text { Apply diluted product, according to label } \\
\text { directions as a dip or spray. (Reg 06/07) }\end{array}$ \\
\hline \multicolumn{4}{|c|}{ Keds } \\
\hline $\begin{array}{l}\text { Atroban } 11 \% \text { EC Insecticide } \\
\text { (permethrin) }\end{array}$ & $\begin{array}{l}\text { Emulsifiable } \\
\text { Concentrate }\end{array}$ & 2 weeks & $\begin{array}{l}\text { Apply diluted product, according to label } \\
\text { directions as a dip or spray. (Reg 06/07) }\end{array}$ \\
\hline $\begin{array}{l}\text { GardStar } 40 \% \text { EC } \\
\text { (permethrin) }\end{array}$ & $\begin{array}{l}\text { Emulsifiable } \\
\text { Concentrate }\end{array}$ & 10-14 days & $\begin{array}{l}\text { Dilute and apply according to label directions. } \\
\text { May be used as a high pressure spray, low } \\
\text { pressure spray (hand-pump sprayer), or } \\
\text { backrubber. (Reg 03/06) }\end{array}$ \\
\hline $\begin{array}{l}\text { Atroban } 11 \% \text { EC Insecticide } \\
\text { (permethrin) }\end{array}$ & $\begin{array}{l}\text { Emulsifiable } \\
\text { Concentrate }\end{array}$ & 2 weeks & $\begin{array}{l}\text { Apply diluted product, according to label } \\
\text { directions as a dip or spray. (Reg 06/07) }\end{array}$ \\
\hline $\begin{array}{l}\text { GardStar } 40 \% \text { EC } \\
\text { (permethrin) }\end{array}$ & $\begin{array}{l}\text { Emulsifiable } \\
\text { Concentrate }\end{array}$ & 10-14 days & $\begin{array}{l}\text { Dilute and apply according to label directions. } \\
\text { May be used as a high pressure spray, low } \\
\text { pressure spray (hand-pump sprayer), or } \\
\text { backrubber. (Reg 03/06) }\end{array}$ \\
\hline $\begin{array}{l}\text { Python Dust } \\
\text { (zeta-cypermethrin) }\end{array}$ & Dust & & $\begin{array}{l}\text { Can be applied by dust bag, shaker can, } \\
\text { dusting glove and mechanical dust applicator. } \\
\text { (Reg 03/06) }\end{array}$ \\
\hline \multicolumn{4}{|c|}{ Mites (Mange) } \\
\hline $\begin{array}{l}\text { Atroban } 11 \% \text { EC Insecticide } \\
\text { (permethrin) }\end{array}$ & $\begin{array}{l}\text { Emulsifiable } \\
\text { Concentrate }\end{array}$ & 2 weeks & $\begin{array}{l}\text { Apply diluted product, according to label } \\
\text { directions as a dip or spray. (Reg 06/07) }\end{array}$ \\
\hline $\begin{array}{l}\text { GardStar } 40 \% \text { EC } \\
\text { (permethrin) }\end{array}$ & $\begin{array}{l}\text { Emulsifiable } \\
\text { Concentrate }\end{array}$ & 10-14 days & $\begin{array}{l}\text { Dilute and apply according to label directions. } \\
\text { May be used as a high pressure spray, low } \\
\text { pressure spray (hand-pump sprayer), or } \\
\text { backrubber. (Reg 03/06) }\end{array}$ \\
\hline
\end{tabular}


Table 4. Registered Insecticides for Specific Goat (lactating and non-lactating) Pests.

\begin{tabular}{|c|c|c|c|}
\hline Insecticide & Formulation & $\begin{array}{l}\text { Re-Treatment } \\
\text { Interval }\end{array}$ & Comments from Label \\
\hline \multicolumn{4}{|c|}{ Mites (Scabies) } \\
\hline $\begin{array}{l}\text { Atroban } 11 \% \text { EC Insecticide } \\
\text { (permethrin) }\end{array}$ & $\begin{array}{l}\text { Emulsifiable } \\
\text { Concentrate }\end{array}$ & 2 weeks & $\begin{array}{l}\text { Apply diluted product, according to label } \\
\text { directions as a dip or spray. (Reg 06/07) }\end{array}$ \\
\hline \multicolumn{4}{|c|}{ Mosquitoes } \\
\hline $\begin{array}{l}\text { Atroban } 11 \% \text { EC Insecticide } \\
\text { (permethrin) }\end{array}$ & $\begin{array}{l}\text { Emulsifiable } \\
\text { Concentrate }\end{array}$ & 2 weeks & $\begin{array}{l}\text { Apply diluted product, according to label } \\
\text { directions as a dip or spray. (Reg 06/07) }\end{array}$ \\
\hline \multicolumn{4}{|c|}{ Stable Flies } \\
\hline $\begin{array}{l}\text { Atroban } 11 \% \text { EC Insecticide } \\
\text { (permethrin) }\end{array}$ & $\begin{array}{l}\text { Emulsifiable } \\
\text { Concentrate }\end{array}$ & 2 weeks & $\begin{array}{l}\text { Apply diluted product, according to label } \\
\text { directions as a dip or spray. (Reg 06/07) }\end{array}$ \\
\hline Catron IV (permethrin) & Aerosol & & $\begin{array}{l}\text { Spray according to label directions. } \\
\text { (Reg 06/07) }\end{array}$ \\
\hline $\begin{array}{l}\text { GardStar } 40 \% \text { EC } \\
\text { (permethrin) }\end{array}$ & $\begin{array}{l}\text { Emulsifiable } \\
\text { Concentrate }\end{array}$ & 10-14 days & $\begin{array}{l}\text { Dilute and apply according to label directions. } \\
\text { May be used as a high pressure spray, low } \\
\text { pressure spray (hand-pump sprayer), or } \\
\text { backrubber. (Reg 03/06) }\end{array}$ \\
\hline Catron IV (permethrin) & Aerosol & & $\begin{array}{l}\text { Spray according to label directions. } \\
\text { (Reg 06/07) }\end{array}$ \\
\hline $\begin{array}{l}\text { GardStar } 40 \% \text { EC } \\
\text { (permethrin) }\end{array}$ & $\begin{array}{l}\text { Emulsifiable } \\
\text { Concentrate }\end{array}$ & 10-14 days & $\begin{array}{l}\text { Dilute and apply according to label directions. } \\
\text { May be used as a high pressure spray, low } \\
\text { pressure spray (hand-pump sprayer), or } \\
\text { backrubber. (Reg 03/06) }\end{array}$ \\
\hline $\begin{array}{l}\text { Python Dust } \\
\text { (zeta-cypermethrin) }\end{array}$ & Dust & & $\begin{array}{l}\text { Can be applied by dust bag, shaker can, } \\
\text { dusting glove and mechanical dust applicator. } \\
\text { (Reg 03/06) }\end{array}$ \\
\hline \multicolumn{4}{|c|}{ Ticks (Ear) } \\
\hline Catron IV (permethrin) & Aerosol & & $\begin{array}{l}\text { Spray according to label directions. } \\
\text { (Reg 06/07) }\end{array}$ \\
\hline
\end{tabular}

